\begin{tabular}{|c|c|}
\hline & $\begin{array}{l}\text { International Journal of Trend in Scientific } \\
\text { Research and Development (IJTSRD) }\end{array}$ \\
\hline 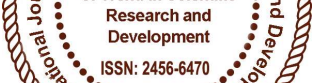 & International Open Access Journal \\
\hline 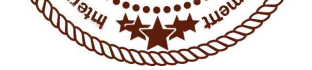 & ISSN No: 2456 - 6470 | www.ijtsrd.com | Volume - 2 | Issue - 2 \\
\hline
\end{tabular}

\title{
A Survey of Passengers Satisfaction on Service Quality of APSRTC: The Case of Prakasam District, A.P
}

\author{
Dr. Chandu Ravi Kumar \\ Assistant Professor, College of Finance, \\ Management \& Development Studies, \\ Ethiopian Civil Services University, Ethiopia
}

\author{
Dr. Ch. Venkata Krishna Reddy \\ Assistant Professor, College of Finance, \\ Management \& Development Studies, \\ Ethiopian Civil Services University, Ethiopia
}

\section{ABSTRACT}

Public transport industry is one of the service sectors, which contributed much to the economy of the country and also plays important role of reducing unemployment. A principal function of public transport industry should be organized around to satisfy the clients. When the passengers are satisfied, then the public services are credited with proving effective service opportunities. Public transport should become part of a solution for sustainable transport in the future. However, in order to keep and attract more passengers, public transport must to have high service quality to satisfy and fulfill more wide range of different customer's needs. To attain this objective, the researchers used a descriptive survey research design. The probability sampling (clustering) was used. The data sources included both primary and secondary ones. Primary data were directly collected from the respondents while secondary data were found from published and unpublished materials such as books, journals and etc. The findings imply that bus stations are not acquainted with basic physical facilities and equipment, such as toilet, waiting place, cafeteria, etc. and presence of problems in personnel service delivery. Most passengers in the data collection sites were complaining about the lack of basic facilities in the bus stations. The findings indicate that passengers are satisfied with the transport services provided with APSRTC.

Keywords: APSRTC, transport, service, passenger, satisfaction

\section{INTRODUCTION}

Transport plays vital role for economic progress and social development of nations. Transportation in general, among other modes, and road transport in particular is the most extensively used transport sector all over the world. The main function of public transport is to offer accessibility of places where people perform activities in rural as well as urban areas. Demand for public transport is defined as the number of people who are willing to travel by public transport. Travellers in public transport are customers. Customers of public transport experience a service product moving them from an origin to a destination. From a customer's point of view, public transport is seen as a transport service. Customer satisfaction is a main issue for transport services. Customer satisfaction is important for the demand and therefore for continuity and profitability of the suppliers of public transport.

Customer satisfaction is one of the crucial aspects service providers should consider especially in today's world where competition has become tremendous and customers have become more knowledgeable. In transport service, passenger satisfaction is an issue that has drawn attention of practitioners, policy makers and academicians. Customer satisfaction is considered to be the most important factor whether it is meant for a product or a service. In case of failure to satisfy the customers the company will be replaced by others and when 
industries offering various services, have to be more vigilant because there is a special attitude that plays an important role attracting and retaining the customers. The underlying assumption is that there is a direct link between the actual service and the customer's perception of it. To increase public transport use, the service should be designed and performed in a way that accommodates the levels of service required by customers.

\section{PROFILE OF APSRTC}

Profile of Andhra Pradesh State Road Transport Corporation: The Andhra Pradesh State Road Transport Corporation (APSRTC) origin dates back to 1932, when it was established as Nizam State Rail and road Transport department (NSR RTD), a wing of Nizam State Railway in the erstwhile Hyderabad State, with 27 buses and 166 employees. During the past 77 years, it has registered a steady growth from 27 to 14,123 buses with 426 bus stations, 128 Depots and 790 bus shelters.

The Corporation's buses cover 43.67 lakhs KMs. and carry 74.71 lakhs people to their destinations every day. They connect 14,123 villages to all major towns and cities in A.P which constitutes 95\% of Road Transport. APSRTC operates to City and Mofussil areas. The Corporation's buses also ply to important towns and cities in the neighboring States/ of Tamilnadu, Karnataka, Odisha, Telangana. The entire network is under the administrative control of 12 Regional Managers in 4 Zones. APSRTC under the present name was established on 11th January 1958 in pursuance of the Road Transport Corporations Act 1950. AAPSRTC has entered the Gunnies Book of World Record for owing largest fleet of buses in the year 1989.

\section{METHODOLOGY}

\section{Research Design}

As it is clearly stated in introduction part, the main purpose of this study was to assess the level of customers' satisfaction on service delivery of APSRTC with reference to Prakasam District. To attain this objective, the researchers used a descriptive survey research design. In order to carry out this research, the researchers contacted the passengers APSRTC, Staff and other concerned bodies with regard to the study theme

\section{Population and Sample}

The researcher chose APSRTC for the purpose of generating the required information. The population was made up of passengers of APSRTC in the Prakasam District.

\section{Data Sources and Data Collection Tools}

The data sources included both primary and secondary ones. Primary data were directly collected from the respondents while secondary data were found from published and unpublished materials such as books, journals, reports, magazines, internet, etc. To collect information from respondents, researchers used questionnaire.

\section{Questionnaire}

A questionnaire with both open-ended and closeended items was originally prepared by researchers. It was initially developed in English and then translated into Teluguto collect information from passengers in the bus stations.

\section{Interview}

Structured interviews were employed to some selected passengers to validate the data collected through questionnaire, and unstructured interviews were used for daily customers from the stations.

\section{Techniques of Data Analysis}

Data gathered using both primary and secondary sources were analyzed by employing both qualitative and quantitative techniques. The Statistical Package for Social Sciences (SPSS version 20.0) was used for data analysis.

\section{RESULTS}

The main objective of this research was to assess passengers' satisfaction on service quality and Satisfaction on services of public transport sector APSRTC. With this regard the following results are explained. 
International Journal of Trend in Scientific Research and Development (IJTSRD) ISSN: 2456-6470

Table 1: Background information of passengers

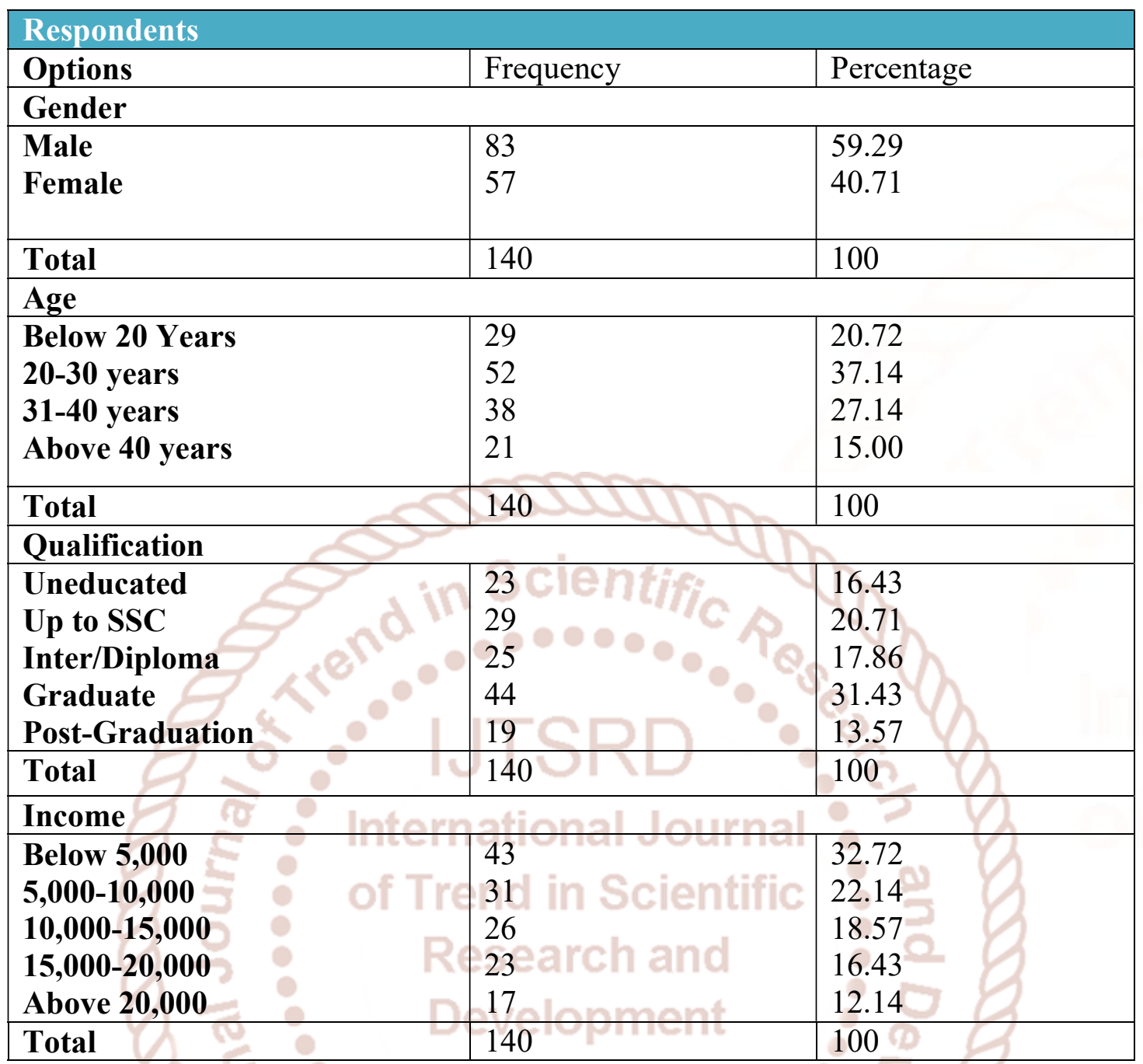

According to Table 1 above, $59.29 \%$ of the respondents were males while the rest $40.71 \%$ were females. Concerning the age of respondents, below 20 were $20.72 \%, 20-30$ were $37.14 \%, 31-40$ were $27.14 \%$, and respondents above 40 were $15 \%$. From this, it can be seen that almost $60 \%$ of the respondent's age is 30 and below it. Concerning the educational status of passengers, nearer to $16.43 \%$ are uneducated, followed by respondents with SSC $20.71 \%$, while $17.86 \%$ of the respondents were Inter/diploma holders, $31.43 \%$ were Graduates and $13.57 \%$ were Post-Graduates. Concerning the income levels of respondents below 5,000 were $32.72 \%$, between $5,000-10,000$ were $22.14 \%, 10,000-15000$ were $18.57 \%, 15,000-20,000$ were $16.43 \%$ and above 20,000 were $12.14 \%$. 
International Journal of Trend in Scientific Research and Development (IJTSRD) ISSN: 2456-6470

Table2: Responses of passengers on service quality indicators

\begin{tabular}{|c|c|c|c|c|c|c|c|c|c|c|c|c|}
\hline \multicolumn{13}{|c|}{ Respondents } \\
\hline \multirow{2}{*}{$\begin{array}{l}\mathrm{S} \\
\mathrm{N} \\
\mathrm{O}\end{array}$} & \multirow{2}{*}{ Items } & \multicolumn{2}{|c|}{$\begin{array}{l}\text { Strongly } \\
\text { Unsa. }\end{array}$} & \multicolumn{2}{|c|}{$\begin{array}{l}\text { Unsatisfie } \\
\text { d }\end{array}$} & \multicolumn{2}{|c|}{$\begin{array}{l}\text { No } \\
\text { comment }\end{array}$} & \multicolumn{2}{|c|}{ Satisfied } & \multicolumn{2}{|c|}{$\begin{array}{l}\text { Strongly } \\
\text { Satisfied }\end{array}$} & \multirow{2}{*}{$\begin{array}{l}\text { Qualit } \\
\mathrm{y} \\
\text { Index }\end{array}$} \\
\hline & & Fre & $\%$ & $\begin{array}{l}\mathrm{Fr} \\
\text { e. }\end{array}$ & $\%$ & $\begin{array}{l}\mathrm{Fr} \\
\text { e. }\end{array}$ & $\%$ & Fre & $\%$ & Fre. & $\%$ & \\
\hline 1 & $\begin{array}{l}\text { There are sufficient physical } \\
\text { facilities and equipment's } \\
\text { (toilet, stay place, cafeteria, } \\
\text { etc) in the bus stations }\end{array}$ & 61 & 43.57 & 38 & 27.14 & 11 & 7.86 & 17 & 12.14 & 13 & 9.29 & 2.45 \\
\hline 2 & $\begin{array}{l}\text { Personnel in the bus stations } \\
\text { look as the standards of the } \\
\text { transport service sector }\end{array}$ & 18 & & 35 & 25 & 13 & & 42 & 30 & 32 & 22.85 & 1.24 \\
\hline 3 & $\begin{array}{l}\text { Personnel in the bus stations } \\
\text { perform activities exactly } \\
\text { and dependably }\end{array}$ & & & 22 & 15.71 & 17 & & 2 & & 15 & 10.71 & 2.13 \\
\hline 4 & $\begin{array}{l}\text { Personnel in the bus station } \\
\text { show readiness to help the } \\
\text { customers }\end{array}$ & 45 & 32 & 31 & 22.14 & 19 & & 2 & & 18 & 12.86 & 1.87 \\
\hline 5 & $\begin{array}{l}\text { Personnel in the bus stations } \\
\text { deliver prompt services }\end{array}$ & 39 & 27.86 & 34 & $\begin{array}{l}\text { In } 5 \\
24.29 \\
10\end{array}$ & 28 & 20 & 24 & 17 & 15 & 10.71 & 1.85 \\
\hline 6 & $\begin{array}{l}\text { Personnel in the bus stations } \\
\text { have knowledge and } \\
\text { politeness of employees }\end{array}$ & 38 & 27 & 41 & 29.28 & 24 & 17 & 26 & 18.57 & 11 & 7.86 & 1.85 \\
\hline 7 & $\begin{array}{l}\text { Personnel in the bus stations } \\
\text { instigate trust and } \\
\text { confidence in delivering } \\
\text { services }\end{array}$ & 40 & 28.57 & 29 & 20.71 & 20 & 12 & 32 & 22.86 & 19 & 13.57 & 1.86 \\
\hline 8 & $\begin{array}{l}\text { Personnel in the bus stations } \\
\text { are caring }\end{array}$ & 50 & 35.72 & 36 & 25.71 & 19 & 13.57 & 22 & 15.71 & 13 & 9.29 & 2.08 \\
\hline
\end{tabular}

As depicted on Table 2about sufficient physical facilities and equipment's (toilet, stay place, cafeteria) in the bus stations, 2.45 quality Index indicated that they disagreed with the presence of basic services in the bus stations. This data implies that bus stations are not acquainted with basic physical facilities and equipment, such as toilet, shower, waiting place, cafeteria, etc. With regard to the Personnel in the bus stations look as the standards of the transport service sector, 1.24 quality Index stated that Personnel in the bus stations look as the standards of the transport service sector. Concerning Personnel in the bus stations perform activities exactly and dependably, almost $56 \%$ of customers disagreed with services. Hence, it can be said that the services provided by personnel are not dependable and accurate. Personnel in the bus station show readiness to help the customers were found to be $(54.28 \%)$ disagreed. Almost half of the passengers $(49 \%)$ responded that they have no trust and confidence with Personnel in 
the bus stations deliver prompt services, while the issue of Personnel in the bus stations has knowledge and politeness of employees was considered, the result shows that $56.5 \%$ of respondents disagreed on the issue. Personnel in the bus stations are caring data implies that $61 \%$ were not satisfied.

\section{Table 3: Responses of Passengers on Service Satisfaction}

\begin{tabular}{|c|c|c|c|c|c|c|c|c|c|c|c|c|}
\hline & \multirow{3}{*}{ Items } & \multirow{2}{*}{\multicolumn{2}{|c|}{\begin{tabular}{|l} 
Strongly \\
Agree
\end{tabular}}} & \multirow{2}{*}{\multicolumn{2}{|c|}{ Agree }} & & & & & \multirow{2}{*}{\multicolumn{2}{|c|}{ Disagree }} & \\
\hline \multirow{2}{*}{$\begin{array}{l}\text { Resp } \\
\text { S. } \\
\text { NO }\end{array}$} & & & & & & \multicolumn{2}{|c|}{$\begin{array}{l}\text { No } \\
\text { comment }\end{array}$} & \multicolumn{2}{|c|}{$\begin{array}{l}\text { Strongly } \\
\text { Disagree }\end{array}$} & & & \multirow[t]{2}{*}{$\begin{array}{l}\text { Satisfactio } \\
\mathrm{n} \text { Index }\end{array}$} \\
\hline & & Fre & $\%$ & Fre & $\%$ & Fre & $\%$ & Fre. & $\%$ & Fre. & $\%$ & \\
\hline 1 & $\begin{array}{l}\text { Are you satisfied with } \\
\text { APSRTC }\end{array}$ & 23 & 16.43 & 34 & 24.29 & 17 & 12.14 & 29 & 20.71 & 37 & 26.43 & 1.87 \\
\hline 2 & $\begin{array}{l}\text { Travel with APSRTC } \\
\text { in future? }\end{array}$ & 27 & 19.29 & 39 & 27.86 & 11 & 7.86 & 36 & 25.71 & 27 & 19.28 & 2.03 \\
\hline 3 & $\begin{array}{l}\text { Recommend to other } \\
\text { people }\end{array}$ & 42 & & 33 & 23.57 & 15 & 10.72 & 31 & 22.14 & 19 & 13.57 & 2.48 \\
\hline
\end{tabular}

According to the table 3, Most of the respondents given their response were strongly disagree and disagree on their satisfaction levels with the APSRTC. Rest of the respondents are satisfied with the APSRTC, it constitute the satisfaction index level is 1.87. Why because the respondents are expecting to reach their desired places with in the stipulated time. In that context the APSRTC are failure to come on time and there is speed limit in that bus due to savage of petrol. In the case of Travel by the APSRTC in the future, Most of the respondents were strongly disagree and disagree. Remaining respondents are satisfied with the APSRTC, it constitute the satisfaction index level is 2.03. It is some extent better when compare to satisfaction with the APSRTC. Why the respondents prefer the APSRTC, the main reason human life is safe due to it is safe and smooth driving by the drivers when compared to private vehicles. Because of that most of the respondents suggested or recommend the APSRTC is safest journey platform to the public. So It is constitute the respondents satisfaction level is 2.48 index on the recommend the APSRTC to other people.

\section{CONCLUSION}

The study showed that drivers and Conductors have problems related to professional ethics in handling passengers. Almost all of the bus stations are not equipped with basic physical facilities (such as toilets, water, showers, waiting rooms, etc). The study reveals that there should be a lot to be done to increase the satisfaction level of passengers in APSRTC in the region. In general, the quality of services in the bus stations, the contemporary knowledge and skill of drivers and Conductors the ethics of service providers need to be intervened. Almost all of the respondents in each category worry about the quality issues at public transport sectors. Therefore, limited service in quality dimensions lead to customers' dissatisfaction at transport sector.

\section{REFERENCES}

1. Kotler, P., 2000, "Principles of Marketing", Prentice Hall, New Delhi.

2. Christopher, H. Loyelock, 1996, "Services Marketing", Prentice Hall International, New Delhi.

3. Rao, A.V.S., 1986, "Service Sector Management In India", Allied Publishers, Hyderabad.

4. India's Transport Sector. The Challenges Ahead, World Bank, May 2002.

5. Integrated Transport Policy, Planning Commission, October, 2001.

6. Report of the National Transport Policy Committee, Planning Commission, May 2009.

7. www.apsrtc.gov.in

8. https://www.consumercomplaints.in/andhrapradesh-state-road-transport-corporation-apsrtcb102088 